\title{
Critical Factors to Achieve Sustainability of Public-Private Partnership Projects in the Water Sector: A Stakeholder-Oriented Network Perspective
}

\author{
Nan He $\mathbb{C}^{1},{ }^{1}$ Yijing Li $\mathbb{D}^{2},{ }^{2}$ Huimin Li $\mathbb{D},{ }^{3}$ Ziqi Liu $\mathbb{D},{ }^{4}$ and Chengyi Zhang $\mathbb{D}^{5}$ \\ ${ }^{1}$ School of Public Administration, North China University of Water Resources and Electric Power, Zhengzhou 450046, China \\ ${ }^{2}$ School of Management and Economics, North China University of Water Resources and Electric Power, \\ Zhengzhou 450046, China \\ ${ }^{3}$ Department of Construction Engineering and Management, North China University of Water Resources and Electric Power, \\ Zhengzhou 450046, China \\ ${ }^{4}$ Xiaolangdi Project Construction and Management Center, Zhengzhou 450000, China \\ ${ }^{5}$ Department of Civil \& Architectural Engineering, University of Wyoming, Laramie, WY 82071, USA
}

Correspondence should be addressed to Huimin Li; lihuimin3646@163.com

Received 14 September 2020; Revised 27 October 2020; Accepted 20 November 2020; Published 30 November 2020

Academic Editor: Guangdong Wu

Copyright (C) $2020 \mathrm{Nan} \mathrm{He}$ et al. This is an open access article distributed under the Creative Commons Attribution License, which permits unrestricted use, distribution, and reproduction in any medium, provided the original work is properly cited.

\begin{abstract}
A key challenge in the management of the public-private partnership project is to understand the critical factors for sustainability performance as well as their complex interaction. Majority of existing studies focus on identifying general factors without consideration of specific context of individual sector. To bridge the gap, unique characteristics of water PPP projects are taken into consideration in this study where the relationship among critical factors to achieve sustainable performance is analyzed from a network perspective. Stakeholder-associated factors and their interrelations were identified via extensive literature review and structured interview, and the social network analysis (SNA) method was employed to recognize the critical factors and their interactions in sustainability achievement of water PPP projects. As a result, seven stakeholder groups and 18 critical factor nodes were identified and further classified into four challenges when achieving sustainability. These challenges are (1) promoting ecological awareness and responsible citizen behaviour; (2) project construction quality; (3) ecological designs and technology innovations; and (4) project management capacity. These findings provide the stakeholders of water PPP projects with useful references for mitigating the risks and facilitating efforts to achieve better sustainability performance.
\end{abstract}

\section{Introduction}

Water is a kind of precious resource that is indispensable and irreplaceable for human life [1]. People have struggled for more than ten-thousand years to manage water resources [2]. With the development of society and technology, many problems in the sustainable supply of water resources have emerged due to the blind pursuit of economic growth, such as frequent drought and flood disasters, sharp decreases of water volume, serious soil erosion, and water pollution. To ensure water security, the water industry, as a key public utility sector in the process of urbanization and industrialization, has attracted much more attention and investment
[3]. According to Aarseth et al. [4], one of the ways to judge the effectiveness of infrastructure construction is whether it can achieve the sustainable goals. Nowadays, sustainability has wide attention from academics, regulators, and businesses [5]. Many scholars believe that investing in infrastructure projects has a significant positive impact on society [6]. However, the long-term sustainable performance of infrastructure projects is sometimes ignored [7] because of the contradiction between local economic benefits and global external costs. This situation is also evident in the water industry as growing level of attention has been paid to the sustainability of water infrastructure projects [8]. Therefore, whether water infrastructure projects can achieve 
sustainability has a significant impact on the development of economy and society as a whole.

Public-private partnership (PPP) is one of the most common models for supplementing infrastructure. As a financing mode, the PPP model has been proven to promote sustainable development [9]. Advanced technology and management experience from the private sector are indispensable for achieving sustainability and ensuring the quality and efficiency of infrastructure projects. Shen et al. [10] analyzed the impact of contribution allocation between the public and the private sectors on infrastructure project sustainability performance. Hueskes et al. [11] considered procurement and management practices to govern the sustainability of PPP projects. Hosseini et al. [12] proposed a framework to discuss the sustainable delivery of megaprojects in Iran. Since water infrastructure projects (including sewage treatment, ecological restoration, and canal irrigation) require specialized technical knowledge and advanced management experience, it is difficult to achieve value of money and to ensure efficiency by relying on the government alone [13]. Besides, funds from the government cannot meet the needs of water infrastructure investment and development [14]. Therefore, combining the technical and management advantages of the private sector and the policy advantages of the government [15], the PPP model has become the main procurement approach of water infrastructure [16]. Although scholars have done numerous studies on the sustainable development of PPP projects, there is little research on the content of water infrastructure projects. Given that sustainability is heavily influenced by content factors [17], it is crucial to analyze these critical factors to achieve sustainability of water PPP projects according to their unique characteristics in the process of achieving sustainability in water infrastructure projects.

Most of the existing studies are either about the sustainable performance evaluation of PPP projects or about critical success factors to achieve sustainability. For example, Büyükzkan and Karabulut [5] reviewed the literature of sustainable performance evaluation from the perspective of private enterprises. Hosseini et al. [12] argued that the improvement of sustainability consciousness, a decrease of corruption, and the enshrinement of project management influenced the sustainable delivery of megaprojects in Iran. It is worth noting that the creation of sustainable indicators is very confusing and lacks consensus [18]. Most of these studies focus on project management from the perspective of major PPP participants, such as the government or the private sector, ignoring the complex network of relationships among stakeholders. This situation leads to obstacles when achieving sustainability in PPP projects. Stakeholders, including the government, the private sector, public individuals, and banks, pursue different interest goals. The behavioral interactions among these stakeholders constitute a complex network of relationships, which has a significant impact on whether a project can achieve sustainability [19]. Different from other kinds of projects, water PPP projects involve more stakeholders that make the interactions more complex and risky [20,21]. It is difficult to achieve sustainability when relying only on the major participants in the project. The cooperation of stakeholders is indispensable. Furthermore, whether the sustainability of water PPP projects is achieved has a bigger influence on society and the economy than other projects. These projects have stronger externalities involving the needs of economic development and the daily life of the public, while they generate fewer user fees. Thus, more effort is required to achieve sustainability. However, in the field of water PPP research, few studies focus on the impact of unique stakeholder groups on sustainable goals, which provides research space for this study. Therefore, the research gaps can be listed as follows:

RQ1: Who are the main stakeholders involved in the process of achieving sustainability in water PPP projects? What factors are generated by these stakeholders that influence the sustainability of water PPP projects?

RQ2: What is the relationship between these factors that affects the achievement of sustainability in water PPP projects?

RQ3: What are the critical factors for achieving sustainability in water PPP projects? And what challenges do these critical factors pose?

This paper adopted the social network analysis method from the perspective of stakeholders to study the critical factors for achieving sustainability of water PPP projects and analyzed the relationship among these factors so as to provide theoretical reference for the governance of water PPP projects.

\section{Literature Review}

2.1. Sustainability of PPP Projects in the Water Sector. Lack of resources, population growth, and climate change has present significant environmental and social challenges. Sustainability is defined as being able to meet current needs without sacrificing the ability of the next generation to meet their needs [22]. This definition has gradually been accepted by organizations and governments globally [23]. In 1997, Elkington [24] put forward the principle of the "Triple Bottom Line" (TBL) to measure sustainability, which refers to meeting the triple standards of the economy, society, and environment. Rijsberman and Van de Ven [25] suggest that sustainability is not only concerned with the needs of several generations but is also related to the capacity of natural supporting systems to maintain the integrity of ecology, environment, and hydrology. Pearce and Vanegas [26] proposed a conceptual model of sustainable infrastructure development to evaluate facility alternative decisions. Steurer and Martinuzzi [27] studied sustainable strategies of European governments. Dhiman [28] extended the definition of the social bottom line from the concept of the labor force and the community to social development and social responsibility. Koppenjan and Enserink [15] distinguished among social, environmental, and financial sustainability in infrastructure construction. However, compared to ecological sustainability, social and economic sustainability has received comparatively less attention [5].

Infrastructure sustainability is an important field in the research of sustainable development. For example, Sahely 
et al. [29] developed a framework for assessing the sustainability of urban infrastructure systems that focuses on key interactions and feedback mechanisms between infrastructure and surrounding environmental, economic, and social systems. Patil et al. [30] proposed a conceptual framework for sustainability assessments of PPP projects, including several sustainable principles based on project efficiency, stakeholders' participation, management capacity, socioecological compatibility, resource utilization, and value of money. Different from the studies on infrastructure sustainability, research on the sustainability of water PPP projects is at an early stage with limited studies. To study the sustainability of PPP, the industry context of PPP's background cannot be ignored [31]. PPP is one of the few options for attracting investment in the water sector while meeting strict environmental standards [32], making it necessary and valuable to study the sustainability of the water PPP projects [33]. It remains a question whether the long-term sustainability of water PPP projects can be achieved [32]. Compared with other projects, water PPP projects have unique characteristics. Firstly, water PPP projects have a greater impact on environmental sustainability. These kinds of projects mainly concentrate on basic infrastructure services that greatly influence the ecological environment, biodiversity, and residents' daily lives, such as drinking water projects, sewage treatment, and watershed management. Secondly, water PPP projects are important tools for realizing social sustainability. Water security has a strong relationship with economic growth and social progress [34]. Academics have paid more attention to water sustainability evaluation than to other topics. Elnaboulsi [35] argued that water reuse and recycling should be one of the sustainable development goals of water infrastructure projects. PellicerMartínez and Martínez-Paz [36] recommended using water footprints to assess environmental sustainability in water management. However, a systematic evaluation method is still under discussion, and most indicators focus on environmental impacts rather than on social and economic impacts. Thirdly, water PPP projects have more stakeholders and more complex relationships [16]. These stakeholders pursue different interest goals. Typical factors considered by the government include the applicability of the PPP model, political influence, affordability of finance and profitability, and public satisfaction. The private sector is concerned more about risk allocation, bidding costs, procurement and supply chain, and internal rate of the return. Public individuals focus on the improvement of water quality and the quality of public services, such as drinking water supply and sewage treatment. Finally, water PPP projects often have difficulties in achieving economic sustainability goals and sustainability of the projects themselves. The reasons are twofold. For one thing, the benefits of these projects are mostly external and social. For another, the income of these projects often comes from government subsidies rather than user fees. Therefore, water PPP projects should not only adapt to regional development and meet the sustainable goals of the triple bottom line but also they should be concerned about the sustainability of the projects themselves, including the quality durability, life-cycle cost, energy consumption, and other aspects [33].

2.2. Stakeholders in Water PPP Projects. The sustainability of PPP projects is affected not only by industrial content factors [17] but also by the interactions among stakeholders [37]. In order to determine the influencing factors for achieving sustainability in water PPP projects, it is a prerequisite to analyze the stakeholders in the project and identify which stakeholders are involved in the process of realizing sustainability.

A stakeholder is "any group or individual who can affect or is affected by the achievement of the organization's objectives" [38]. Due to the complexity of modern infrastructure projects, there are multiple stakeholders in modern construction projects, and the application of stakeholder management is becoming more and more important, ensuring the efficiency and quality of projects is not a matter up to just one party but a collective effort of all parties in the partnership [39]. Edwards et al. [40] analyzed the critical success factors of PPP projects from the perspective of stakeholders. Ismail [41] studied the implementation of PPP projects in Malaysia and found that good governance, fulfillment of contracts, and a good market and legal environment were critical for project success. Goel et al. [42] applied the social network analysis method to analyze the relationship between stakeholders, pointing out that construction workers, communities, public individuals, and end users were all stakeholders of the project. Stakeholders have conflicting interests and concerns, which may devastate the project if mismanaged. In addition, long-term contracts of PPP projects led to dynamic relationship during the project lifecycle [43], leading to a shift of responsibility among stakeholders at different stages [44]. Thus, stakeholders are seen as key determinants of project success and they must be managed in a more structured manner.

Some scholars have conducted research in the field of water PPP projects specifically. Furlong and Bakker [20] analyzed the involvement of stakeholders in water infrastructure projects, including the government, nongovernmental organizations, independent institutions, private companies, financial institutions, and urban water enterprises. Amadi et al. [21] teased out the development of China's water PPP projects and recognized three kinds of investors: a domestic investment company with abundant capital, private water enterprises with professional experience, and local operators. However, compared with research on PPP projects, few studies have focused on water projects and influencing factors on sustainability in water PPP projects from the perspective of stakeholders, leaving research space for this study.

Water PPP projects have several unique characteristics in terms of stakeholders. The organizational structure of water PPP projects is more complex, involving more stakeholder groups than general PPP projects. As to the public sector, it is necessary to distinguish between the general public and water dwellers. These stakeholders are the 
people who can influence the realization of the organization's goals or the individuals and groups affected by the organization's goal process [45]. According to the existing research $[16,33,46]$ on PPP project stakeholders, this paper puts forward the classification of stakeholders of water PPP projects. The classification is shown in Table 1.

\subsection{Critical Factors on Sustainability of Water PPP Projects.} Critical factor analysis is a basic part of scientific problem analysis, which is essential for understanding the mechanism of real problems and the behavior pattern of participants. Analyzing critical factors to achieve sustainability is not only conducive to the construction of a practical concept framework for the sustainable performance evaluation of PPP projects but also helps participants to improve project quality and efficiency.

Most studies on the sustainability of PPP projects are still based on the triple bottom line. To be specific, economic sustainability means that the project can bring stable investment returns in its life-cycle, and that is can have a positive impact on local economic development [47]. Social sustainability refers to the improvement of public goods and services for the public, more employment opportunities, and development potential for the local region in which the project is being conducted [42]. Ecological sustainability means that a balance has been achieved between the ecological system and the natural system, ensuring intergenerational equity of the environment [48].

In addition, based on the triple bottom line, some scholars have proposed more dimensions, such as resource and project sustainability, in the sustainable performance evaluation. Amiril et al. [49] explored the relationship between influencing factors on sustainability and the performance of transport projects, identifying several factors concerning the environment, economy, society, engineering, resource utilization, and project management. Li et al. [33] analyzed 27 influencing factors that affect the sustainability of water PPP projects and divided them into five dimensions, namely economy, society, resources and environment, engineering, and project management.

In terms of assessing sustainability, different countries have adopted different criteria and dimensions. CEEQUAL in the UK evaluates the sustainability of infrastructure by considering 12 aspects, including project environment management, use of materials, water issues, ecology and biodiversity, and waste [50]. GREENROAD is a system to assess the sustainability of road projects in the USA with 11 project requirements and 37 voluntary activities that can be divided into five dimensions: environment and water, access and equity, construction activities, materials and resources, and pavement technologies [51]. The infrastructure Sustainability Council of Australia has proposed the Infrastructure Susatinability (IS) comprehensive evaluation system, which divides sustainability into four dimensions called the quadruple bottom line of sustainability [52]. These sustainability rating systems are widely used in the infrastructure market, quantifying the influencing factors of sustainability with the aim of enabling practitioners to understand and take measures to meet sustainable standards and achieve infrastructure sustainability.

This paper draws on quadruple bottom line in the comprehensive evaluation system of IS and divided influencing factors into four dimensions, that are dimensions of economy, society, ecology, and governance.

Although studies have been carried out various studies on sustainable goals, sustainable performance evaluations, and sustainable delivery, there are few analyses and discussions of the factors affecting sustainability in water PPP projects. Therefore, based on the unique characteristics of water PPP projects and existing research, this paper proposed four dimensions on the basis of the quadruple bottom line and 16 specific factors, which can be seen in Table 2 .

\section{Methodology and Processes}

\subsection{Methodology}

3.1.1. Social Network Analysis. Social network analysis (SNA) is an effective tool for researchers to simulate organizational structures and analyze interactions between different individuals or groups. This method assumes that network members can influence each other and that their behavior is largely influenced by the interaction patterns in the network structure [77]. As an effective method to study stakeholders, SNA has been widely applied in construction project management [78]. Some scholars use the SNA method to visualize the complex relationship network of stakeholders [79].

A network is a way of thinking about social systems and relationships between entities, which are called actors or nodes. In this paper, the SNA method is adopted to analyze the critical factors for achieving sustainability and the correlation between those factors from the perspective of stakeholders involved in water PPP projects. SNA is used in this study because this approach can quantify the interaction between different factors in the network. In the process of water PPP project construction and implementation, both the behaviors and decisions of stakeholders have an impact on the sustainable development of the project. These influences are interwoven to form a complex impact network. For instance, the financial pressure of local government in the implementation of a project will affect the sustainable cash flow of the project company, thus affecting the achievement of sustainability in the water PPP project. Neither factor is independent; rather, both are interrelated. These factors and the relationships between factors form a network structure. The SNA method is a set of norms and methods to analyze the relationship and structure of this kind of network, which, in turn, can better explain the structure and properties of the network. Therefore, the SNA approach is applied in this paper to answer the second research question, that is, what is the relationship between these factors that affects the achievement of sustainability in water PPP projects?

All nodes are encoded in the form of $S_{x} L_{y}$, where $S_{x}$ represents the stakeholder groups and $L_{y}$ represents the factors to achieve sustainability. For example, $S_{2} L_{9}$ 
TABLE 1: Stakeholders in water PPP projects.

\begin{tabular}{|c|c|}
\hline Stakeholders & Subclass (context) \\
\hline Local government & $\begin{array}{c}\text { Local government departments leading the project, such as the water bureau, regulatory agencies, environmental } \\
\text { protection bureau }\end{array}$ \\
\hline Private company & The private company that is responsible for the investment, management, and operation of the whole project \\
\hline SPV & The company established for the project specially \\
\hline Financial investors & Including banks, urban construction investment company owned by government, PPP funds \\
\hline $\begin{array}{l}\text { Construction } \\
\text { company }\end{array}$ & The enterprise department responsible for project construction but not involved in the project investment \\
\hline General public & \\
\hline Water dweller & Residents living near the bodies of water that are directly affected by or make impacts on the project \\
\hline
\end{tabular}

TABLE 2: List of critical factors influencing sustainability in water PPP projects.

\begin{tabular}{|c|c|c|c|}
\hline Dimension & Factors & Content & Literature source \\
\hline \multirow{4}{*}{ Economy } & Value of money in lifecycle & $\begin{array}{l}\text { The effort made to meet the VFM requirement } \\
\text { during the entire project lifecycle }\end{array}$ & Xiong and Zhu [47]; Ugwu et al. [53] \\
\hline & Sustainable cash flow & $\begin{array}{l}\text { The project can produce stable and reasonable cash } \\
\text { flow during its lifecycle }\end{array}$ & Shen et al. [54]; Shen et al. [55] \\
\hline & $\begin{array}{l}\text { Fiscal pressure of } \\
\text { government }\end{array}$ & $\begin{array}{l}\text { The financial pressure on the local government } \\
\text { when investing in the project }\end{array}$ & Li et al. [33]; Wang and Zhao [56] \\
\hline & $\begin{array}{l}\text { Value-added benefits to land } \\
\text { around the projects }\end{array}$ & $\begin{array}{c}\text { The project may improve the living or business } \\
\text { environment in the project's surrounding area, } \\
\text { which may add value to the land and increase the } \\
\text { fiscal revenue }\end{array}$ & $\begin{array}{l}\text { Li et al. [33]; Yılmaz and Bakış [48]; Shen } \\
\text { et al. [55] }\end{array}$ \\
\hline \multirow{4}{*}{ Society } & \multirow{4}{*}{$\begin{array}{c}\text { Corporate-social } \\
\text { responsibility } \\
\text { Legal underpinning and } \\
\text { institutional arrangements } \\
\text { Government management } \\
\text { capacity }\end{array}$} & $\begin{array}{l}\text { The index to evaluate the satisfaction degree of } \\
\text { people regarding the project and local government }\end{array}$ & $\begin{array}{c}\text { Kivilä et al. [57]; Mavi and Standing [58]; } \\
\text { Heravi et al. [59] }\end{array}$ \\
\hline & & $\begin{array}{l}\text { The awareness of responsibility for a corporation to } \\
\text { contribute to the improvement of society }\end{array}$ & $\begin{array}{l}\text { Hosseini et al. [12]; Hueting [60]; } \\
\text { Hutchins and Sutherland [61] }\end{array}$ \\
\hline & & $\begin{array}{l}\text { The governing structure, regulation system, and } \\
\text { market arrangement of the project region }\end{array}$ & $\begin{array}{l}\text { Hosseini et al. [12]; Banerjee et al. [62]; } \\
\text { Ménard et al. [63] }\end{array}$ \\
\hline & & $\begin{array}{l}\text { The capacity of the government to manage the } \\
\text { project }\end{array}$ & Patil et al. [30]; House [64] \\
\hline \multirow{4}{*}{ Ecology } & Effect on water quality & $\begin{array}{c}\text { The changes of water quality, including drinking } \\
\text { water quality, and sewage treatment }\end{array}$ & $\begin{array}{l}\text { Shen et al. [54]; Shen et al. [55]; Li et al. } \\
\text { [65]; Lundin and Morrison [66] }\end{array}$ \\
\hline & $\begin{array}{l}\text { Reduction of energy } \\
\text { consumption }\end{array}$ & $\begin{array}{l}\text { The reduction of energy consumption during the } \\
\text { project construction }\end{array}$ & Shen et al. [55]; Ugwu et al. [53] \\
\hline & $\begin{array}{l}\text { Usage of recycled material } \\
\text { and green innovation } \\
\text { technology }\end{array}$ & $\begin{array}{c}\text { Adoption of recycled construction material and } \\
\text { innovation technology during the project } \\
\text { construction and operation }\end{array}$ & $\begin{array}{l}\text { Begum et al. [67]; Hewage and Porwal } \\
\text { [68]; Brown and Sovacool [69]; Ugwu } \\
\text { and Haupt [70] }\end{array}$ \\
\hline & Ecology and biodiversity & $\begin{array}{c}\text { Adoption of measures to maintain a healthy } \\
\text { ecological environment and protect various kinds } \\
\text { of animals and plants }\end{array}$ & Yılmaz and Bakış [48] \\
\hline \multirow{4}{*}{ Governance } & Construction quality & The construction quality of the project & Silvius and Schipper [71] \\
\hline & $\begin{array}{l}\text { Trust and communication } \\
\text { among organizations }\end{array}$ & $\begin{array}{c}\text { Reflecting relationships and interactions between } \\
\text { different stakeholders }\end{array}$ & House [64]; Allouche and Finger [72] \\
\hline & Management capacity & $\begin{array}{c}\text { Including contract management capacity, risk } \\
\text { management capacity, and operation management } \\
\text { capacity }\end{array}$ & $\begin{array}{c}\text { Beh [73]; Liu and Yamamoto [74]: Chou } \\
\text { and Pramudawardhani [75] }\end{array}$ \\
\hline & Environmental design & $\begin{array}{c}\text { Adopting an environmentally friendly project } \\
\text { design }\end{array}$ & $\begin{array}{l}\text { Ugwu et al. [53]; Shen et al. [76]; Li et al. } \\
\text { [65] }\end{array}$ \\
\hline
\end{tabular}

represents the effort of a private company to improve water quality during the project construction phrase. Furthermore, several indicators in the SNA method are used to analyze the network, such as density, degree of node, brokerage, and betweenness centrality [77].

Moreover, several nodes which do not exist in practice were deleted. In order to determine which nodes needed to be removed, this study conducted a presurvey before data collection. Two experts in academia and one in engineering construction were invited to justify the existence of nodes in the network. All three experts have had extensive experience in water PPP projects for at least three years. By summarizing the experts' opinions and literature reviews, each of the factors and relationships between the factors and stakeholders groups was analyzed, and several nodes were deleted. For example, financial investors can only affect the 
financial management and cash flow of the project. They cannot affect the evaluation and improvement of value of money in each phase of the project lifecycle. Thus, node $S_{4} L_{1}$ (improvement of value of money in lifecycle by financial investors) was deleted. A total of 38 similarly illogical nodes were deleted. All nodes encoded and deleted are listed in Table 3 .

3.1.2. Research Framework. Yu et al. [80] and Zheng et al. [81] pointed out that integrating the traditional framework with the SNA approach can effectively identify critical factors and various interactions in the complex relationship of stakeholders. The main steps of this study are (1) identifying the factors influencing sustainability from the stakeholders' perspective in water PPP projects; (2) filtering and removing nodes that do not exist in practice; (3) analyzing the factors and relationships from the perspective of stakeholders; (4) offering management implementation recommendations based on research results. The detailed framework is shown in Figure 1.

3.2. Data Collection and Processes. This paper adopted the method of a structured interview to collect relevant data. This approach can reduce the ambiguity caused by unclear semantics in the process of information collection and transmission. Because this study was conducted from the perspective of stakeholders, the interview also followed the sampling principle of stakeholder orientation [82]. According to the analysis in Section 2.2, a total of seven stakeholder groups are involved in this study and two representatives were selected from each of the groups for the interview. $S_{1}$ representatives came from the local water department. $S_{2}$ and $S_{3}$ representatives are project managers in a water corporation and water PPP project company, respectively. $S_{4}$ representatives are credit managers of a large commercial bank in charge of the water utilities PPP project. $S_{5}$ representatives were selected from a large construction company. $S_{6}$ and $S_{7}$ representatives were randomly selected from local public individuals and residents living within the scope of water PPP projects. All interviewees in groups $S_{1}$ to $S_{5}$ had to have more than two years' experience in water PPP project management or practice to be selected. Ultimately, 14 invitees were identified as qualified interviewees. The sample size meets the requirements of data analysis as established in the previous studies [80].

The project representatives were interviewed using the structured interview approach to identify potential links between influencing factors. To ensure the accuracy of the interviewees' understanding, the authors gave an oral explanation in detail regarding the research background and each factor, which was helpful for judging the directional influence relationship between the factors. For instance, $S_{m} L_{n}$ and $S_{x} L_{y}$ represent two different nodes. If there is a link from $S_{m} L_{n}$ to $S_{x} L_{y}$, this demonstrates that $S_{m} L_{n}$ can affect $S_{x} L_{y}$. Thus, all interviewees were asked to respond to the following two questions: (1) does $S_{m} L_{n}$ affect $S_{x} L_{y}$ during the achievement of sustainability in water PPP projects (the existence and direction of the link)? (2) If $S_{m} L_{n}$ affects $S_{x} L_{y}$, to what degree can $S_{m} L_{n}$ influence $S_{x} L_{y}$ (the degree of influence)? In the first question, if the link between the two factors does not exist, then it is represented by " 0 ." The responses to the second question were measured by a fivelevel Likert scale (where " 1 " refers to the lowest level and " 5 " refers to the highest level).

During the interview, when two interviewees in the same stakeholder group had different opinions, discussion was used to obtain consensus. If they could not arrive at an agreement, the interviewees invited another representative in the same stakeholder group to make a judgment and reach a consensus.

After the data collection, this study adopted the SNA approach to conduct analysis using Ucinet 6 and Netdraw. Indicators of network density, network cohesion, nodal degree, betweenness centrality, closeness centrality, and brokerage were employed to present the critical features of the network and then to identify key factors and stakeholders.

\section{Results}

4.1. Relational Network Model. Based on the social network analysis approach, a network of critical factors influencing the sustainability of water PPP projects was constructed. This network is a relational network model formed by the interaction and association of various influencing factors. There is a directional influence relationship between nodes, which can be identified by the strength of the ties. In this study, seven stakeholder groups and 16 factors that affect the sustainability of water PPP projects were determined and divided into four categories. A total of 74 network nodes were obtained, forming 5256 links. The network drawn by the NetDraw program is shown in Figure 2. Here, the shapes of nodes represent different stakeholders, and the color of nodes represents different factor categories. The lines with arrow indicate the directional relationship between a pair of nodes. The distance between two nodes refers to the influence degree of the relationship. Node icons with greater degree centrality indicate greater size.

\subsection{Analysis of Relational Network Model}

4.2.1. Overall Network Level Results. The overall network density refers to the proportion of actual links presenting within a network to the maximum number of potential links if all network actors are interconnected with each other [79]. The results showed that the network density is $0.720>0.5$, and the average distance between nodes is 1.280 . The distance-based cohesion of the network is 0.860 . These findings indicate that the network is intensive, and all factors are closely related to each other. Factors interact and produce a chain reaction. In addition, the out-degree network centralization is $27.09 \%$, while in-degree is $24.87 \%$. The distribution of network nodes is relatively symmetrical, but the network degree centralization is low, indicating that there is no significant central tendency on the network level and that 
TABLE 3: Coding of stakeholder groups and influencing factors in water PPP projects.

\begin{tabular}{lcccc}
\hline & Stakeholders & & Factors & Deleted nodes \\
\hline$S_{1}$ & Local government & $L_{1}$ & Value of money in lifecycle & $S_{4} L_{1}$ \\
\hline$S_{2}$ & Private company & $L_{2}$ & Sustainable cash flow & $S_{6} L_{2}, S_{7} L_{2}$ \\
\hline$S_{3}$ & SPV & $L_{3}$ & Fiscal pressure of government & $S_{6} L_{3}, S_{7} L_{3}$ \\
\hline$S_{4}$ & Financial investors & $L_{4}$ & Value-added benefits to land around the projects & $S_{4} L_{4}, S_{6} L_{4}$ \\
\hline \multirow{2}{*}{$S_{5}$} & Construction company & $L_{5}$ & Public satisfaction & $S_{4} L_{5}$ \\
& $L_{6}$ & Corporate-social responsibility & $S_{6} L_{6}, S_{7} L_{6}$ \\
\hline$S_{6}$ & General public & $L_{7}$ & Legal underpinning and institutional arrangements & $S_{2} L_{7}, S_{3} L_{7}, S_{4} L_{7}, S_{5} L_{7}, S_{6} L_{7}, S_{7} L_{7}$ \\
\hline & & $L_{8}$ & Government management capacity & $S_{2} L_{8}, S_{3} L_{8}, S_{4} L_{8}, S_{5} L_{8}, S_{6} L_{8}, S_{7} L_{8}$ \\
& $L_{9}$ & Effect on water quality & $S_{4} L_{9}$ \\
& & $L_{10}$ & Reduction of energy consumption & $S_{4} L_{10}, S_{6} L_{10}, S_{7} L_{10}$ \\
$S_{7}$ & Water dweller & $L_{11}$ & Usage of recycled material and green innovation technology & $S_{4} L_{11}, S_{6} L_{11}, S_{7} L_{11}$ \\
& $L_{12}$ & Ecology and biodiversity & $S_{4} L_{12}$ \\
& $L_{13}$ & Construction quality & $S_{4} L_{13}, S_{6} L_{13}$ \\
& & $L_{14}$ & Trust and communication among organizations & $S_{6} L_{14}, S_{7} L_{14}$ \\
& & $L_{15}$ & Management capacity & $S_{4} L_{15}, S_{7} L_{15}$ \\
& $L_{16}$ & Environmental design & $S_{4} L_{16}, S_{7} L_{16}$ \\
\hline
\end{tabular}

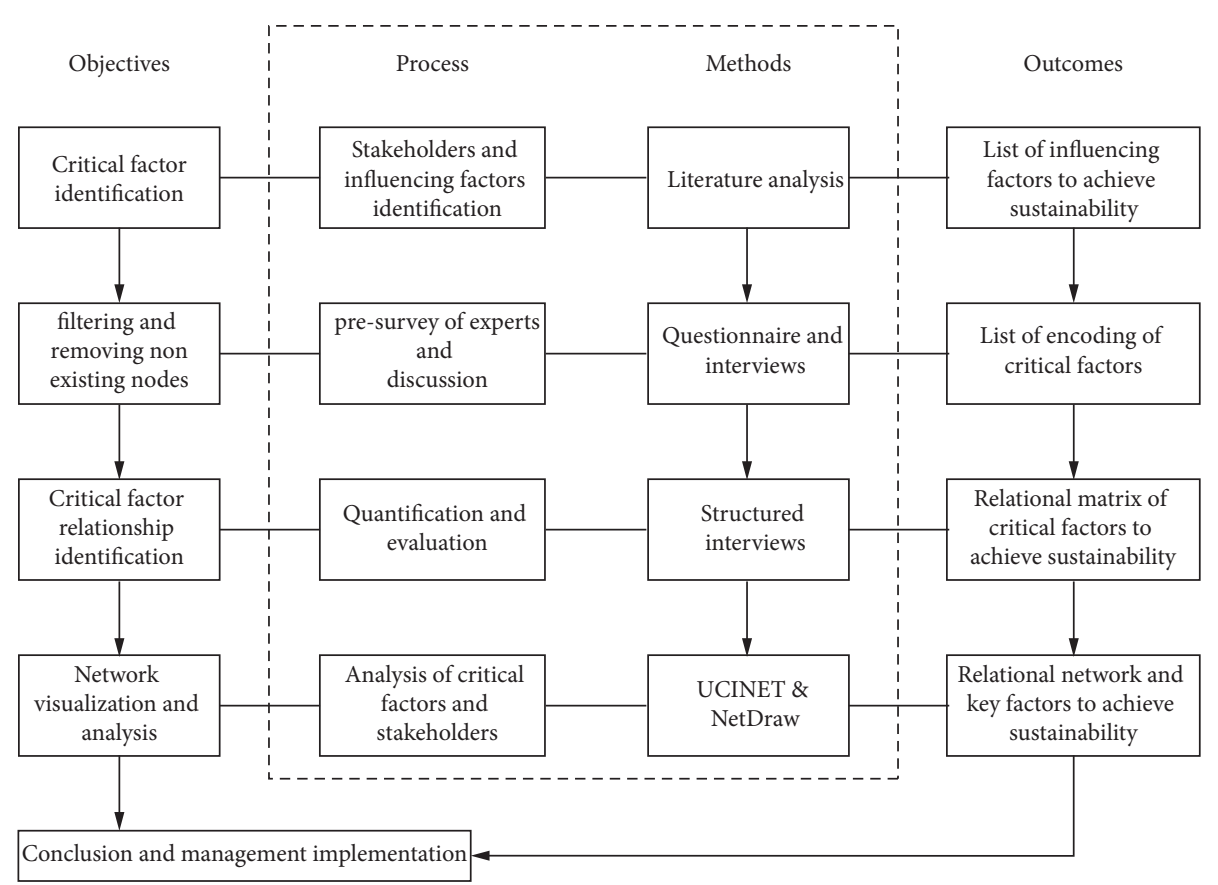

FIGURE 1: Research framework.

the nodes are relatively dispersed. Therefore, the governance of these influencing factors is very challenging.

From the perspective of stakeholders in water PPP projects, local governments play a central role, followed by private sectors and construction companies. Financial investors and the public have little influence. This is mainly because governments are responsible for policy formulation, guidance, and implementation in the process of social governance and sustainable development. From the perspective of the factor categories, the quality of the project is the most important factor in sustainability achievement, followed by environmental factors; social and economic factors are relatively marginal.
4.2.2. Node and Link Level Results. In this paper, nodes and links are analyzed using several measures, including node degree centrality, betweenness centrality, closeness centrality, and brokerage. These indicators show the importance of nodes from different perspectives.

(1) Degree Centrality. Degree centrality reflects the degree of aggregation of relationships between nodes, indicating the capability of nodes to measure their resources and influence. In weighted digraphs, degree centrality can be divided into in-degree and out-degree. Table 4 lists the top 10 degree centrality nodes. It should be noted that 5 nodes rank top 10 in different indicators, including S1L13, S1L7, S2L13, S7L5, 


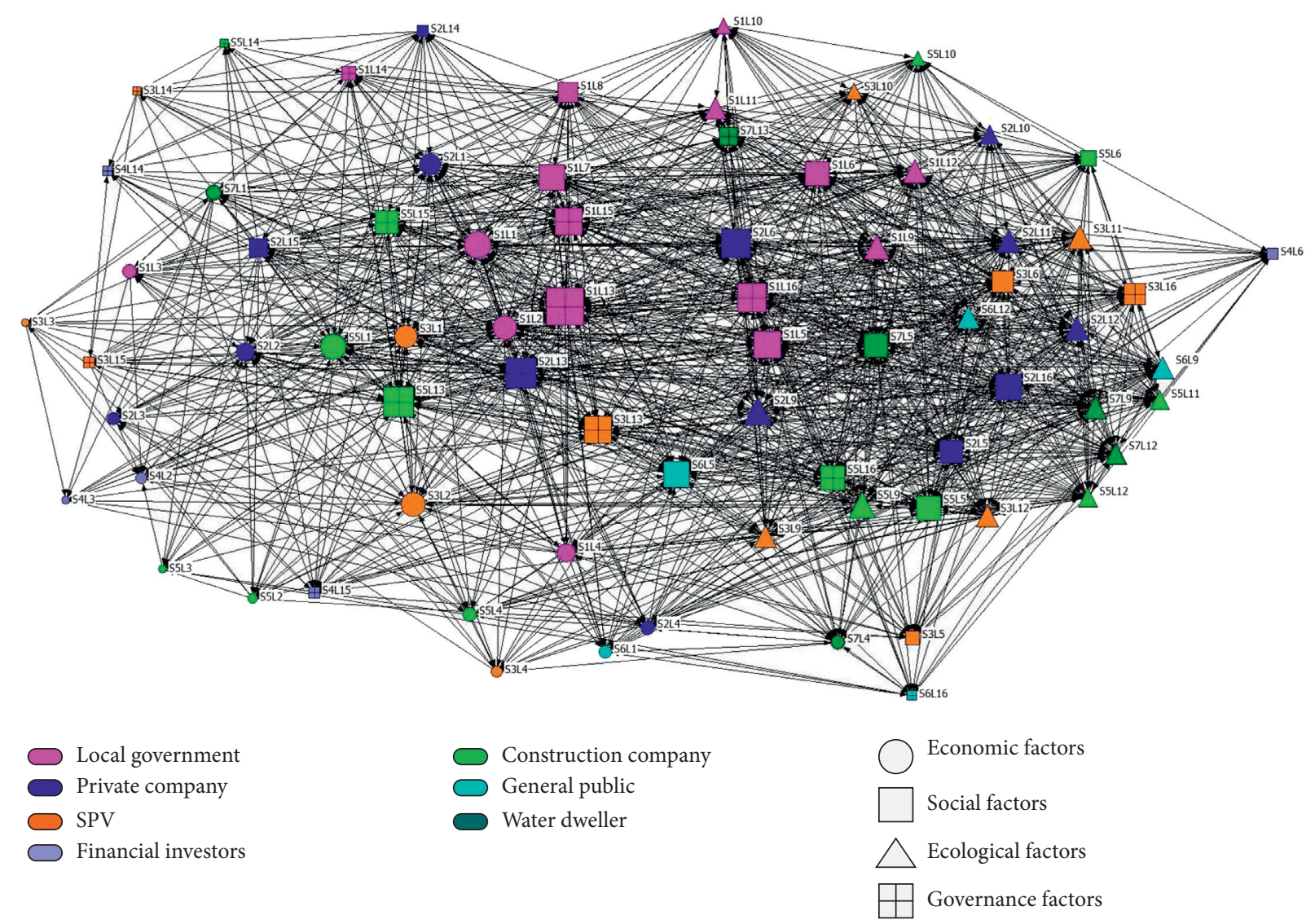

FIGURE 2: Stakeholder-associated influencing factor network.

TABLE 4: Top factors based on point centrality and degree analyses.

\begin{tabular}{lcccccc}
\hline Ranking & Factor ID1 & Out degree & Factor ID2 & In degree & Factor ID3 & Degree difference \\
\hline 1 & $S_{2} L_{6}$ & 260 & $S_{7} \mathbf{L}_{\mathbf{5}}$ & 252 & $S_{\mathbf{1}} \mathbf{L}_{7}$ & 157 \\
2 & $S_{\mathbf{1}} \mathbf{L}_{\mathbf{1 3}}$ & 255 & $\boldsymbol{S}_{\mathbf{6}} \mathbf{L}_{\mathbf{5}}$ & 245 & $S_{4} L_{15}$ & 134 \\
3 & $\mathbf{S}_{\mathbf{1}} \mathbf{L}_{\mathbf{1 5}}$ & 254 & $\boldsymbol{S}_{\mathbf{1}} \mathbf{L}_{\mathbf{1 3}}$ & 234 & $S_{4} L_{6}$ & 119 \\
4 & $S_{\mathbf{1}} \mathbf{L}_{\mathbf{7}}$ & 251 & $S_{1} L_{5}$ & 231 & $S_{4} L_{3}$ & 107 \\
5 & $S_{1} L_{16}$ & 244 & $S_{2} L_{1}$ & 217 & $S_{1} L_{8}$ & 102 \\
6 & $S_{\mathbf{2}} \mathbf{L}_{\mathbf{1 3}}$ & 240 & $S_{7} L_{13}$ & 212 & $S_{5} L_{11}$ & 93 \\
7 & $S_{5} L_{13}$ & 233 & $S_{7} L_{9}$ & 211 & $S_{4} L_{14}$ & $S_{3} L_{5}$ \\
8 & $S_{5} L_{16}$ & 230 & $S_{3} L_{1}$ & 207 & $S_{7} \mathbf{L}_{\mathbf{5}}$ & 85 \\
9 & $S_{3} L_{2}$ & 226 & $S_{2} L_{5}$ & 206 & $S_{\mathbf{6}} \mathbf{L}_{\mathbf{5}}$ & 79 \\
\hline
\end{tabular}

and S6L5, indicating that these factors have a significant impact on the whole network.

The results showed that $S_{2} L_{6}$ (social responsibility of private sector) has the largest out-degree centrality of 260 , followed by $S_{1} L_{13}$ (project quality improvement by local government), $S_{1} L_{15}$ (project management capacity of local government), $S_{1} L_{7}$ (legal underpinning and institutional arrangements by local government), and $S_{1} L_{16}$ (environmental design decided by local government). These factors have a direct influence on other factors, belonging to local government and the private sector separately. This indicates that these two stakeholder groups occupy key positions of influence in water PPP projects.
Node $S_{7} L_{5}$ (public satisfaction of the project from water dwellers) has the maximum in-degree centrality of 252, followed by $S_{6} L_{5}$ (public satisfaction of the project from general public). Ranking third to fifth are $S_{1} L_{13}$ (project quality improvement by local government), $S_{1} L_{5}$ (public satisfaction improvement by local government), and $S_{2} L_{1}$ (improvement of value of money in lifecycle by private sector). These factors are most directly affected by other factors in the network, thus probably leading to the failure of sustainability in water PPP projects. Notably, $S_{1} L_{13}$ and $S_{2} L_{13}$ rank in the top 10 in both out-degree and in-degree centrality, demonstrating that the efforts of the government and the private sector on project quality are key factors to achieve sustainability in water PPP projects. Not only can they 
greatly influence other factors, but also they can be affected by many factors. $S_{1} L_{7}$ has very high out-degree centrality, but it has very low in-degree centrality, indicating that it has a greater impact on other factors than other factors have on it. Conversely, $S_{7} L_{5}$ and $S_{6} L_{5}$ have high in-degree centrality and low out-degree centrality, which means these two factors are more likely to be influenced by other factors.

(2) Betweenness Centrality. Betweenness centrality calculates the occurrence in which a specific node is situated between other pairs on the basis of the shortest path [83]. It measures whether a node serves as an intermediary. The greater the betweenness centrality, the stronger is its ability to control other factors [84]. Table 5 shows the top 10 nodes based on betweenness centrality.

According to the results, five of the top 10 key nodes focused on the project-level. The highest betweenness centrality came from $S_{1} L_{13}$ (project quality improvement by local government) with 0.757 , followed by $S_{1} L_{15}$ (project management capacity of local government), $S_{1} L_{16}$ (environmental design decided by local government), $S_{1} L_{2}$ (maintaining sustainable cash flow by local government), $S_{3} L_{2}$ (maintaining sustainable cash flow by SPV), and $S_{3} L_{1}$ (improvement of Value of Money in lifecycle by SPV). These nodes play a mediating role in the network and have a stronger ability to transmit influence as a result. Compared to other stakeholders, government departments and SPV companies are the main transmitters of sustainable influencing factors in water PPP projects.

(3) Closeness Centrality. Closeness centrality indicates the degree to which a node is not controlled by other nodes [84]. It calculates the sum of the shortest distance between a pair of nodes on the graph, which is used to measure the dependence of one actor on the other. The top 10 nodes are listed in Table 6.

The calculation results show that $S_{5} L_{3}$ (public satisfaction improvement by construction company), $S_{1} L_{7}$ (legal underpinning and institutional arrangements improvement by government), and $S_{6} L_{1}$ (improvement of value of money in project lifecycle by general public) have the largest outcloseness centrality, indicating that these nodes are highly independent and not easily affected by others. $S_{4} L_{6}$ (social responsibility of financial investors), $S_{4} L_{15}$ (project management capacity of financial investors), and $S_{4} L_{3}$ (reduced fiscal pressure of government by financial investors) have the largest in-closeness centrality, which means that these nodes have a high degree of closeness to the center of the network and may affect other factors independently.

(4) Brokerage. Brokerage is the indicator that describes the role and capability of a certain node to bridge different subgroups within a network. There are five different roles in brokerage measures, including Coordinate (all nodes belong to same group), Gatekeeper (the source belongs to a different group), Representative (the recipient belongs to a different group), Itinerant (the broker belongs to a different group), and Liaison (all nodes belong to different groups) [85]. The top 10 nodes are listed in Table 7 . These nodes play a crucial
TABLE 5: Critical influencing factors based on betweenness centrality.

\begin{tabular}{lcc}
\hline Ranking & Factor ID & Node betweenness centrality \\
\hline 1 & $S_{1} L_{13}$ & 0.757 \\
2 & $S_{1} L_{15}$ & 0.734 \\
3 & $S_{1} L_{16}$ & 0.706 \\
4 & $S_{1} L_{2}$ & 0.704 \\
5 & $S_{3} L_{2}$ & 0.675 \\
6 & $S_{3} L_{1}$ & 0.674 \\
7 & $S_{7} L_{5}$ & 0.595 \\
8 & $S_{7} L_{9}$ & 0.593 \\
9 & $S_{2} L_{13}$ & 0.572 \\
10 & $S_{2} L_{15}$ & 0.569 \\
\hline
\end{tabular}

TABLE 6: Top factors based on closeness centrality.

\begin{tabular}{lcccc}
\hline Ranking & Factor ID & InCloseness & Factor ID & OutCloseness \\
\hline 1 & $S_{4} L_{6}$ & 132 & $S_{5} L_{3}$ & 108 \\
2 & $S_{4} L_{15}$ & 128 & $S_{1} L_{7}$ & 108 \\
3 & $S_{4} L_{3}$ & 126 & $S_{6} L_{1}$ & 106 \\
4 & $S_{4} L_{14}$ & 126 & $S_{5} L_{11}$ & 106 \\
5 & $S_{3} L_{14}$ & 117 & $S_{3} L_{4}$ & 102 \\
6 & $S_{6} L_{16}$ & 117 & $S_{3} L_{10}$ & 102 \\
7 & $S_{5} L_{14}$ & 113 & $S_{2} L_{14}$ & 102 \\
8 & $S_{3} L_{12}$ & 110 & $S_{7} L_{1}$ & 102 \\
9 & $S_{3} L_{5}$ & 109 & $S_{3} L_{11}$ & 102 \\
10 & $S_{3} L_{15}$ & 109 & $S_{5} L_{4}$ & 102 \\
\hline
\end{tabular}

role in bridging the stakeholder groups, so these factors are also critical to the sustainability of water PPP projects.

The results show that $S_{1} L_{13}$ (project quality improvement by local government) ranks first in the brokerage analysis, ranking first in the Gatekeeper, Itinerant, and Liaison roles. $S_{1} L_{15}$ (public satisfaction improvement by local government), $S_{3} L_{1}$ (improvement of Value of Money in lifecycle by SPV), $S_{1} L_{2}$ (maintaining sustainable cash flow by local government), and $S_{1} L_{16}$ (environmental design decided by local government) rank from second to fifth place in total brokerage, indicating that local governments are the key actors in bridging different factors and stakeholders within the network. $S_{2} L_{6}$ (social responsibility of private sector) should also be noted for its first place rank in the Coordinate and Representative roles in the brokerage analysis.

\section{Critical Factors and Challenges to Achieving Sustainability in Water PPP Projects}

5.1. The Framework of Critical Factors and Challenges. In Section 4, several indicators were analyzed from the network level and node level. Considering the ranking of different measures, this study finally identified 18 critical factor nodes according to the calculation results, as shown in Table 8 . These nodes generally rank in the top 10 in multiple measure indicators.

The 18 key nodes are unevenly distributed across the four dimensions. Thereunto, the governance dimension ranks first with seven factor nodes, followed by the social 
TABLE 7: Top stakeholder-associated factors based on brokerage analysis.

\begin{tabular}{|c|c|c|c|c|c|c|}
\hline Factor ID & Coordinate & Gatekeeper & Representative & Itinerant & Liaison & Total \\
\hline$S_{1} L_{13}$ & 21 & 168 & 121 & 155 & 635 & 1100 \\
\hline$S_{1} L_{15}$ & 15 & 127 & 122 & 149 & 605 & 1018 \\
\hline$S_{3} L_{1}$ & 23 & 123 & 165 & 137 & 551 & 999 \\
\hline$S_{1} L_{2}$ & 12 & 115 & 124 & 152 & 593 & 996 \\
\hline$S_{1} L_{16}$ & 11 & 124 & 98 & 146 & 614 & 993 \\
\hline$S_{3} L_{2}$ & 10 & 89 & 141 & 150 & 578 & 968 \\
\hline$S_{2} L_{6}$ & 58 & 145 & 216 & 100 & 421 & 940 \\
\hline$S_{2} L_{13}$ & 21 & 130 & 122 & 124 & 528 & 925 \\
\hline$S_{7} L_{9}$ & 20 & 91 & 138 & 118 & 541 & 908 \\
\hline$S_{7} \mathrm{~L} 5$ & 15 & 105 & 105 & 134 & 547 & 906 \\
\hline
\end{tabular}

TABLE 8: Recognition of critical factors and challenges according to the integrated network indicators.

\begin{tabular}{|c|c|c|c|}
\hline $\begin{array}{l}\text { Critical } \\
\text { factors }\end{array}$ & Factor explanations & $\begin{array}{l}\text { Corresponding } \\
\text { stakeholders }\end{array}$ & Main challenge \\
\hline$S_{2} L_{6}$ & Social responsibility of private sector & Private company & \multirow{6}{*}{$\begin{array}{l}\text { 1. The challenge of promoting ecological } \\
\text { awareness and citizen behavior }\end{array}$} \\
\hline$S_{3} L_{5}$ & Public satisfaction improvement by SPV company & SPV & \\
\hline$S_{4} L_{6}$ & Social responsibility of financial investors & Financial investors & \\
\hline$S_{6} L_{5}$ & Public satisfaction of general public & General public & \\
\hline$S_{7} L_{5}$ & Public satisfaction of water dwellers & & \\
\hline$S_{7} L_{9}$ & Improvement to water quality by water dweller & Water dwellers & \\
\hline$S_{1} L_{2}$ & Maintaining sustainable cash flow by local government & & \multirow{4}{*}{$\begin{array}{l}\text { 2. The challenge of project construction } \\
\text { quality }\end{array}$} \\
\hline$S_{1} L_{13}$ & $\begin{array}{c}\text { Project construction quality improvement by local } \\
\text { government }\end{array}$ & Local government & \\
\hline$S_{2} L_{13}$ & $\begin{array}{l}\text { Project construction quality improvement by private } \\
\text { sector }\end{array}$ & Private company & \\
\hline$S_{3} L_{2}$ & Maintaining sustainable cash flow by SPV company & SPV & \\
\hline$S_{1} L_{16}$ & Environmental design decided by local government & Local government & \multirow{4}{*}{$\begin{array}{l}\text { 3. The challenge of adopting ecological } \\
\text { design and technological innovation }\end{array}$} \\
\hline$S_{3} L_{11}$ & $\begin{array}{l}\text { Usage of recycled material and green innovation } \\
\text { technology decided by SPV company }\end{array}$ & SPV & \\
\hline$S_{5} L_{11}$ & $\begin{array}{l}\text { Usage of recycled material and green innovation } \\
\text { technology decided by construction company }\end{array}$ & Construction & \\
\hline$S_{5} L_{16}$ & $\begin{array}{c}\text { Environmental design decided by construction } \\
\text { company }\end{array}$ & company & \\
\hline$S_{1} L_{15}$ & Project management capacity of local government & Local government & \multirow{4}{*}{$\begin{array}{l}\text { 4. The challenge of project management } \\
\text { capacity }\end{array}$} \\
\hline$S_{3} L_{1}$ & $\begin{array}{l}\text { Improvement of value of money in project lifecycle by } \\
\qquad \text { SPV company }\end{array}$ & SPV & \\
\hline$S_{4} L_{14}$ & $\begin{array}{l}\text { Improvement of trust and communication among } \\
\text { organizations by financial investors }\end{array}$ & Financial investors & \\
\hline$S_{4} L_{15}$ & Project management capacity of financial investors & & \\
\hline
\end{tabular}

dimension with five factor nodes. Both, the economy and ecology dimensions have three factor nodes. This is a slight departure from common sense about sustainability. It is generally believed that people pay more attention to the ecology dimension when talking about sustainability, but the research results show that stakeholders are more concerned about the governance dimension of water PPP projects and believe that factors in this dimension are more important for achieving sustainability. The reasons are twofold. On the one hand, the importance of social sustainability and project governance are often neglected because sustainability is generally considered to be an ecological development issue. On the other hand, scholars and practitioners focus more on the ecologic and economic dimensions of sustainability and usually take measures to improve the sustainability of the projects in these two aspects.
From the perspective of stakeholders, it can be seen that the stakeholders with the largest proportion of nodes are from the local government and SPV companies, while the stakeholder with the smallest proportion is the general public. This situation is consistent with the practice of water PPP projects. It should be noted that financial investors also play a significant role in the process of achieving sustainability, accounting for a proportion of nodes second only to the government and SPV companies. This is mainly because water PPP projects cannot generate enough user fees. Thus, determining how to ensure sufficient funds are raised to meet the construction and operation costs of the project is a key factor for the success of the project, making the financial investor a significant stakeholder.

In order to better understand these critical nodes, this paper identified four major challenges for water PPP projects 
based on the distribution of nodes in the four dimensions when achieving sustainability. The framework of critical factors and challenges is shown in Figure 3.

\subsection{Four Main Challenges to Achieving Sustainability}

5.2.1. The Challenge of Promoting Ecological Awareness and Responsible Citizen Behavior. Ecological awareness is a kind of ideological concept, reflecting the public's attention to environmental issues, the level of environmental protection knowledge, the behavior of participating in protection activities, and whether enterprises can take the initiative to take actions for environmental protection. Based on the calculation results, the first challenge for water PPP projects to achieve sustainability is that enterprises and citizens have insufficient ecological awareness, leading to some behaviors and decisions that may hinder sustainable development in the process of the project construction and operation. A total of six critical nodes were identified in this challenge, namely, $S_{2} L_{6}, S_{3} L_{5}, S_{4} L_{6}, S_{6} L_{5}$, $S_{7} L_{5}$, and $S_{7} L_{9}$, and they were involved in five stakeholder groups (private sector, SPV, financial investors, general public, and water dweller). These factors can be divided into two categories. One is affecting the sustainability of water PPP projects through the social responsibility of participants; the other is affecting sustainability through public satisfaction with the project.

The first category of factors came from the private sector and financial investors. A private company is the core participant in a project because it takes responsibility for project design, construction, and operation. Its behavior has a significant impact on the project in the process of achieving sustainability. Meanwhile, financial investors play an irreplaceable role in the implementation of the project. The private sector and financial investors with good social responsibility are more willing to take measures to reduce pollution in construction, promote environmental protection, improve water quality, and conserve biodiversity. On the other hand, participants with poor social responsibility pay more attention to their own economic interests and even ignore environmental protection requirements to reduce construction costs [76]. Social responsibility emphasizes ethical behavior related to the economy, society, and environment, making it similar to the triple-bottom line of sustainable development.

The second category of factors influences the sustainability of the project through changes in public satisfaction. Public involvement can play an active role in infrastructure delivery [86] and public engagement contributes to delivering a sustainable and resident service [87]. On one hand, the main way to enhance public satisfaction with an SPV company is to improve project performance and the environment effectively. If public satisfaction is low, SPV companies and private companies are vulnerable to reputation damage, which will affect the sustainable delivery of PPP projects [88]. On the other hand, public individuals, especially water dwellers, have a direct impact on the ecological environment around the project area. When the level of public satisfaction is high, public individuals not only can help to advance the project construction process but also they can regulate themselves to avoid destructive behaviors [89], such as waste water dumping, illegal water creature capture, and watershed vegetation damage. Ecological awareness on the part of the public can push them to voluntarily take measures to the project environment and ecology.

To meet the challenge of promoting ecological awareness and responsible citizen behavior, it is necessary to continuously improve the sustainability awareness of project stakeholders [12]. Private companies, SPV companies, and financial investors need to strengthen their sense of social responsibility. Social responsibility is a necessity for an enterprise to thrive long term, especially for companies involved in water PPP projects. A good sense of social responsibility and sustainability awareness is not only important for the construction and operation of water infrastructure projects but also for gaining a competitive advantage in the field of the infrastructure market. The behavior of the general public and water dwellers relies largely on local government policies and guidance. For the reason that citizens commonly took local government to protect their interests [89], the local government should strengthen the education of the public and the publicity of environmental protection, creating an atmosphere of environmental protection throughout the entire society and encouraging environmentally responsible citizen behavior of the public. Not only that the government departments should introduce more incentive measures and policies enabling PPP projects to cultivate the social responsibility of private companies and financial investors.

\subsubsection{The Challenge of Project Construction Quality.} According to Yuan et al.'s framework of the sustainability of PPPs, project construction quality is the basic condition and prerequisite to achieve sustainability [90]. The construction quality of a water PPP project is related to the successful delivery of the project and the realization of value of money in the project lifecycle. This challenge involves four critical nodes, namely, $S_{1} L_{2}, S_{1} L_{13}, S_{2} L_{13}$, and $S_{3} L_{2}$. Project construction quality is not only related to project safety during the project lifecycle, but it also can reduce the cost of project operation. If quality problems occur in the project, such as construction collapse, they will have a significant impact on society, economy, and environment.

Generally, all stakeholders agree that the quality of the project itself is an important factor influencing sustainable performance. Among these stakeholders, local government and the private sector have the greatest impact on project construction quality. The reason is that in the PPP model, private companies have rights to make decisions during the implementation of the project, while local government not only has the power to initiate projects but also to act in a supervisory capacity. In addition, sustainable cash flow is an effective embodiment of the economic sustainability of water PPP projects [47]. Sustainable cash flow occupies the key 


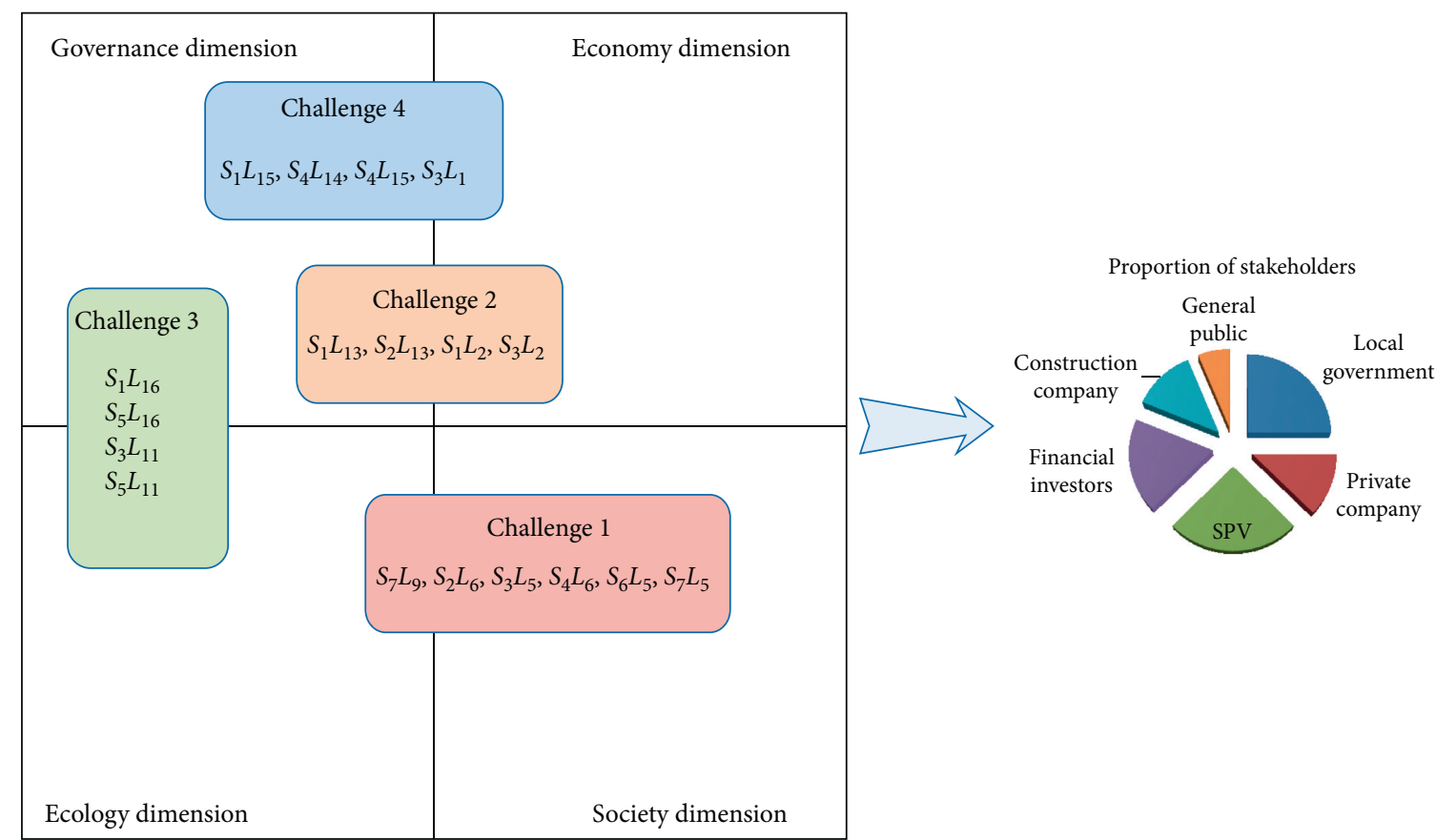

Figure 3: The framework of critical factors and challenges.

position in ensuring project construction quality due to the irreplaceable importance of cash flow management in any engineering project. The sustainability of cash flow is the top priority for the existence and smooth progress of projects. In the construction process, sufficient funds for construction are necessary, while during the operation period, sustainable cash inflow can guarantee recovery and operating expenses for private sectors. Not only does it have a direct impact on the stability and sustainability of projects but the private sector takes cash flow as a significant indicator of economic profit. In quasi-profit water PPP projects, the main stakeholders affecting the sustainable cash flow are the local government and SPV companies. The former is the main source of project benefits, while the latter is the main manager of project fund use. Thus, SPV companies should integrate sustainable impacts concerns into project construction to promote economic development and decrease the frequency of environmental accidents [91].

From the factor analysis, it can be seen that the stakeholders of water PPP projects concur that the construction quality of a project is the critical factor affecting sustainability, which indicates that water PPP projects themselves universally have some quality problems. This is mainly attributed to the complex structure and relationships, high technical content, and luck of definite user fee PPP project, leading to opportunistic behaviors of governments or private sector [92]. In order to improve the construction quality, several measures should be taken in every phase of project lifecycle, so as to effectively improve project performance and achieve sustainable development goals. For example, the local government should optimize project planning and construction regulation. The SPV companies may improve engineering construction quality and take responsible for quality control.
5.2.3. The Challenge of Adopting Ecological Designs and Technological Innovations. Whether or not environmental designs and innovative technologies are adopted in water PPP projects does not necessarily affect the construction success of the projects. However, these factors have a great impact on the sustainability of the project [93] because adopting ecological designs and technological innovations can decrease social and environmental costs of the projects, so as to influence the sustainability [94]. Kivilä et al. [57] emphasized the importance of project planning when achieving sustainable goals. The challenge of adopting ecological designs and technology innovations is focused on four critical nodes, $S_{1} L_{16}, S_{3} L_{11}, S_{5} L_{11}$, and $S_{5} L_{16}$, all of which involve the local government, SPV, and construction companies. Firstly, adopting environmentally friendly designs or adopting innovative technology usually results in higher costs than traditional designs and technology. SPV companies are not willing to consider environmental factors in project construction unless there are administrative requirements or incentive measures from local government departments. Therefore, under the control of legislation and regulations, the government has played a leading role in promoting the adoption of clean technologies at the project level [95]. Secondly, SPV companies have considerable power in making the decision to adopt innovative technology, for they are the specific implementers and purchasers of the project. As the most important power in facilitating sustainable development, technological innovation is much easier to be adopted by private sector, such as private companies and SPV [96]. In practice, SPV companies act as key participants connecting multiple stakeholder groups of the projects and promoting the cooperation of all participants so as to improve the design quality and constructability of the projects, especially when adopting new 
technologies [97]. Finally, construction companies occupy two of the four key nodes because they always suffer insufficient liquidity when adopting new technologies [98]. Although the government and SPV companies may have environmentally-friendly designs, construction companies are likely to take a perfunctory attitude toward them due to the lack of funds and management capacity. This will not only cause a waste of resources, but it will also hinder the achievement of sustainability in water PPP projects.

To cope with the challenge of adopting ecological designs and technological innovations, multisector cooperation is necessary. The government must take incentive measures and create restriction regulations to encourage the usage of environmental innovations and designs [99]. For example, incentive policies should be established for projects that adopt environmental design and technology according to the sustainability of their performance. The private sector as a leading party should exert subjective positivity with a strong sense of social responsibility to initiate the adoption of ecological designs and technological innovations. Doing so is conducive to the sustainability of development as well as to the reduction of operating cost. The SPV companies have a duty to coordinate with other stakeholders. Financial investors should pay more attention to maintaining the sustainable cash flow of the projects, ensuring that sufficient funds are available for adopting ecological designs and green technology. To sum up, the stakeholders should proceed by considering the overall situation and taking the project lifecycle sustainable performance into consideration.

\subsubsection{The Challenge of Project Management Capacity.} Last but not least is the challenge of the project management capability of stakeholders. This challenge involves three stakeholder groups and four key nodes. Many scholars have studied the sustainability of infrastructure projects from the perspective of project management. Many constraints were identified, such as inadequate training of project managers [100], lack of sustainability awareness [101], and weak execution capacity [54]. There is no doubt that project management capability has been a critical factor for project sustainable delivery for a long time. In practice, however, the main participants in water PPP projects still face a shortage of stakeholders' project management capacity. For government departments, critical factors, such as weak project governance management and poor operation capacity, restrict the sustainable development of the projects [87]. The results also confirm Chan et al.'s findings that management capacity of SPV companies has a significant impact on PPP success [102]. Especially in water PPP projects with long contract periods and complex structures, the emergency management capacity of the government and SPV companies is particularly important when facing accidents and management shocks [13]. Differing from Du et al. argument [94], the results of this study emphasize the financing ability of financial investors instead of private sector in sustainability achievement of water PPP projects. As one of the key stakeholder groups of water PPP projects, financial investors are irreplaceable to guarantee sufficient funds, reduce financial costs, and maintain sustainable cash flow. However, in practice, the management capacity of financial investors is often neglected, which hinders the sustainable development of water PPP projects.

Therefore, to achieve sustainability performance, it is imperative to enhance the project management capacity of all stakeholders. For one thing, each stakeholder should take initiative to strengthen management training, carry out target management, make emergency plans, and diversify risks reasonably. For the government, the most important thing is to optimize personnel teams, reduce redundant approval processes, and introduce modern enterprise management experience and tools. Financial investors should establish a professional project evaluation team to prevent various financial risks that may occur in the construction and operation of the project. For another thing, stakeholders must strengthen their communication and cooperation and cultivate trust relationships among organizations in order to improve operation efficiency and realize the sustainability of the project.

\section{Conclusions}

The sustainability of water PPP projects is affected by multiple factors and stakeholder groups, which are interrelated with each other, forming a complex network. This study started by using a literature review and expert interviews to identify seven stakeholder groups and 16 critical factors that can positively or negatively affect water PPP projects in achieving sustainability. Then, the social network analysis (SNA) method was adopted to discuss the influencing factors and their complicated relationships from the perspective of stakeholders. An influencing factor relationship network model was constructed based on the results of a structured interview, and a systematic analysis was conducted on the nodes through an index analysis. Finally, four key challenges affecting sustainability in water PPP projects were identified based on 18 critical influencing factors. Different from other existing studies, this study exposes the network complexity that is often ignored in traditional approaches, which improves the effectiveness and accuracy of stakeholder and factor analysis.

According to research results, four key challenges were identified: (1) the challenge of promoting ecological awareness and responsible citizen behavior; (2) the challenge of project construction quality; (3) the challenge of adopting ecological designs and technological innovations; and (4) the challenge of project management capacity. Considering that these challenges are the major developmental bottlenecks that hinder the achievement of sustainability in water PPP projects, several management measures are proposed to deal with these challenges.

This paper contributes to the literature in three aspects. First, the factors influencing sustainability have been identified for water PPP projects specifically. The research results make up for the lack of industry background in the current research on the topic of the sustainability of PPP projects. This paper focuses on the characteristics of water PPP projects specifically, providing new theoretical support 
for the sustainable development of water PPP projects. Second, a comprehensive view of critical factors and stakeholders has been theorized using the SNA method to analyze influencing relationships in the complex network from the perspective of stakeholders. This provides a new research perspective for the body of knowledge about influencing factors of sustainability. Third, the results bridge the existing gap caused by the lack of empirical evidence to understand the influencing mechanism of sustainability achievement in water PPP projects. For one thing, the existing theoretical results are verified in this paper. For another thing, new research problems and perspectives are put forward. For instance, the results emphasize the impact of financial investors on project sustainability. Future studies could focus on the financing models and investment decision-making behaviors of financial investors in water PPP projects. In addition, this study provides a useful reference for how stakeholders of water PPP projects can take measures to achieve sustainability in practice, and it also enlightens other PPP infrastructure project managements about how to achieve sustainable goals.

The limitations of this study are as follows. (1) Not all stakeholder groups were listed in the research. A total of seven core stakeholder groups were studied. However, there are other stakeholder groups that were not included, such as material suppliers and third-party consulting agencies. (2) Due to the complexity of data collection, the identification of critical factors and relationships was conducted based only on the cognition of 14 interviewees. As such, there may be some subjective bias in the recognition of relationships between influencing factors. Therefore, future research may invite a wider range of stakeholders to conduct follow-up studies from a more comprehensive perspective.

\section{Data Availability}

The data used to support the findings of this study are available from the corresponding author upon request.

\section{Conflicts of Interest}

The authors declare that there are no conflicts of interest regarding the publication of this paper.

\section{Acknowledgments}

The authors acknowledge with gratitude the MOE (Ministry of Education in China) Project of Humanities and Social Sciences (no. 19YJC630078), Chinese National Fund of Social Science (17CJY005), the National Natural Science Foundation of China (nos. 71302191 and 71974056), National Key R\&D Program of China (no. 2018YFC0406905), Youth Talents Teachers Scheme of Henan Province Universities (no. 2018GGJS080), Philosophy and Social Science Research Project of Universities in Henan Province (2017YYZD-04), China Scholarship Council (no. 201908410388), Social Science Project of Henan Province (2020JJX26), and the PhD Innovation Fund of North China University of Water Resources and Electric Power (2020). This study would not have been possible without their financial support.

\section{References}

[1] H. H. Savenije, "Why water is not an ordinary economic good, or why the girl is special," Physics Chemistry of the Earth Parts A/B/C, vol. 27, no. 11-22, pp. 741-744, 2002.

[2] S. Mithen, Thirst: For Water and Power in the Ancient World, Harvard University Press, Cambridge, MA, USA, 2012.

[3] E. E. Ameyaw and A. P. Chan, "A fuzzy approach for the allocation of risks in public-private partnership waterinfrastructure projects in developing countries," Journal of Infrastructure Systems, vol. 22, no. 3, Article ID 04016016, 2016.

[4] W. Aarseth, T. Ahola, K. Aaltonen, A. Ø.lton, and B. Andersen, "Project sustainability strategies: a systematic literature review," International Journal of Project Management, vol. 35, no. 6, pp. 1071-1083, 2017.

[5] G. Büyükzkan and Y. Karabulut, "Sustainability performance evaluation: literature review and future directions," Journal of Environmental Management, vol. 217, pp. 253-267, 2018.

[6] N. A. Gil, G. Biesek, and J. Freeman, "Inter organizational development of flexible capital designs: the case of futureproofing infrastructure," IEEE Transactions on Engineering Management, vol. 62, no. 3, pp. 335-350, 2015.

[7] Y. She, L. Shen, L. Jiao, J. Zuo, V. W. Y. Tam, and H. Yan, "Constraints to achieve infrastructure sustainability for mountainous townships in China," Habitat International, vol. 73, pp. 65-78, 2018.

[8] H. Tan and J. Fu, Sustainable Energy and Green Finance for a Low-Carbon Economy Perspectives from the Greater Bay Area of China, Springer International Publishing, New York, NY, USA, 2020.

[9] S. Lenferink, T. Tillema, and J. Arts, “Towards sustainable infrastructure development through integrated contracts: experiences with inclusiveness in Dutch infrastructure projects," International Journal of Project Management, vol. 31, no. 4, pp. 615-627, 2013.

[10] L. Shen, V. Tam, L. Gan, K. Ye, and Z. Zhao, "Improving sustainability performance for public-private-partnership (PPP) projects," Sustainability, vol. 8, no. 3, p. 289, 2016.

[11] M. Hueskes, K. Verhoest, and T. Block, "Governing publicprivate partnerships for sustainability," International Journal of Project Management, vol. 35, no. 6, pp. 1184-1195, 2017.

[12] M. R. Hosseini, S. Banihashemi, I. Martek, H. Golizadeh, and F. Ghodoosi, "Sustainable delivery of megaprojects in Iran: integrated model of contextual factors," Journal of Management in Engineering, vol. 34, no. 2, Article ID 05017011, 2018.

[13] X. An, H. Li, L. Wang, Z. Wang, J. Ding, and Y. Cao, "Compensation mechanism for urban water environment treatment PPP project in China," Journal of Cleaner Production, vol. 201, pp. 246-253, 2018.

[14] J. Zhu, "Local developmental state and order in China's urban development during transition," International Journal of Urban and Regional Research, vol. 28, no. 2, pp. 424-447, 2004.

[15] J. F. M. Koppenjan and B. Enserink, "Public-private partnerships in urban infrastructures: reconciling private sector participation and sustainability," Public Administration Review, vol. 69, no. 2, pp. 284-296, 2010.

[16] A. Shrestha, T. K. Chan, A. A. Aibinu, C. Chen, and I. Martek, "Risk allocation inefficiencies in Chinese PPP 
water projects," Journal of Construction Engineering Management Accounting Research, vol. 144, no. 4, 2018.

[17] A. Hakiminejad, C. Fu, and H. Mohammadzadeh Titkanlou, "A critical review of sustainable built environment development in Iran," Proceedings of the Institution of Civil Engineers-Engineering Sustainability, vol. 168, no. 3, pp. 105-119, 2015.

[18] T. Ramos and S. M. Pires, "Sustainability assessment: the role of indicators," Sustainability Assessment Tools in Higher Education Institutions, Springer, Berlin, Germany, 2013.

[19] G. Wu, J. Zuo, and X. Zhao, "Incentive model based on cooperative relationship in sustainable construction projects," Sustainability, vol. 9, no. 7, 2017.

[20] K. Furlong and K. Bakker, "The contradictions in "alternative" service delivery: governance, business models, and sustainability in municipal water supply," Environment and Planning C: Government and Policy, vol. 28, no. 2, pp. 349-368, 2010.

[21] C. Amadi, P. Carrillo, and M. Tuuli, "Stakeholder management in PPP projects: external stakeholders' perspective," Built Environment Project and Asset Management, vol. 8, no. 4, pp. 403-414, 2018.

[22] S. W. S. WCED, "World commission on environment and development," Our Common Future, vol. 17, pp. 1-91, 1987.

[23] E. G. Satolo and A. T. Simon, "Critical analysis of assessment methodologies for intraorganizational sustainability," Management of Environmental Quality: An International Journal, vol. 26, no. 2, pp. 214-232, 2015.

[24] J. Elkington, "The "triple bottom line" for twenty-first-century business," in Companies in a World of Conflict: NGOs, Sanctions Corporate ResponsibilityEarthscan, London, UK, 1998.

[25] M. A. Rijsberman and F. H. M. Van de Ven, "Different approaches to assessment of design and management of sustainable urban water systems," Environmental Impact Assessment Review, vol. 20, no. 3, pp. 333-345, 2000.

[26] A. R. Pearce and J. A. Vanegas, "Defining sustainability for built environment systems: an operational framework," International Journal of Environmental Technology Management, vol. 2, no. 1-3, pp. 94-113, 2002.

[27] R. Steurer and A. Martinuzzi, "Towards a new pattern of strategy formation in the public sector: first experiences with national strategies for sustainable development in Europe," Environment and Planning C: Government and Policy, vol. 23, no. 3, pp. 455-472, 2005.

[28] S. Dhiman, "Products, people, and planet: the triple bottomline sustainability imperative," Journal of Global Business Issues, vol. 2, no. 2, pp. 51-57, 2008.

[29] H. R. Sahely, C. A. Kennedy, and B. J. Adams, "Developing sustainability criteria for urban infrastructure systems," Canadian Journal of Civil Engineering, vol. 32, no. 1, pp. 72-85, 2005.

[30] N. A. Patil, D. Tharun, and B. Laishram, "Infrastructure development through PPPs in India: criteria for sustainability assessment," Journal of Environmental Planning and Management, vol. 59, no. 4, pp. 708-729, 2016.

[31] R. Kates and W. Clark, Our Common Journey: A Transition toward Sustainability, National Academy Press, Washinton, DC, USA, 1999.

[32] N. Qian, S. House, A. M. Wu, and X. Wu, "Public-private partnerships in the water sector in China: a comparative analysis," International Journal of Water Resources Development, vol. 36, no. 4, pp. 631-650, 2020.
[33] H. Li, Q. Xia, S. Wen, L. Wang, and L. Lv, "Identifying factors affecting the sustainability of water environment treatment public-private partnership projects," Advances in Civil Engineering, vol. 2019, Article ID 7907234, 15 pages, 2019.

[34] D. E. Garrick, J. W. Hall, A. Dobson et al., "Valuing water for sustainable development," Science, vol. 358, no. 6366, pp. 1003-1005, 2017.

[35] J. C. Elnaboulsi, "An efficient pollution control instrument: the case of urban wastewater pollution," Environmental Modeling \& Assessment, vol. 16, no. 4, pp. 343-358, 2011.

[36] F. Pellicer-Martínez and J. M. Martínez-Paz, "The water footprint as an indicator of environmental sustainability in water use at the river basin level," Science of the Total Environment, vol. 571, pp. 561-574, 2016.

[37] F. Ceschin, "Critical factors for implementing and diffusing sustainable product-service systems: insights from innovation studies and companies' experiences," Journal of Cleaner Production, vol. 45, pp. 74-88, 2013.

[38] R. E. Freeman, Strategic Management: A Stakeholder Approach, Cambridge University Press, Cambridge, UK, 1951.

[39] U. K. Partnerships, PFI: Strengthening Long-Term Partnerships, HM Treasury U.K: Crown, London, UK, 2006.

[40] P. Edwards, J. Shaoul, A. Stafford, and L. Arblaster, Evaluating the Operation of PFI in Roads and Hospitals, Vol. 84, Certified Accountants Educational Trust, London, UK, 2004.

[41] S. Ismail, "Critical success factors of public private partnership (PPP) implementation in Malaysia," Asia-Pacific Journal of Business Administration, vol. 5, no. 1, pp. 6-19, 2013.

[42] A. Goel, L. S. Ganesh, and A. Kaur, "Social sustainability considerations in construction project feasibility study: a stakeholder salience perspective," Engineering Construction Architectural Management, vol. 27, no. 7, pp. 1429-1459, 2020.

[43] W. Zou, M. Kumaraswamy, J. Chung, and J. Wong, "Identifying the critical success factors for relationship management in PPP projects," International Journal of Project Management, vol. 32, no. 2, pp. 265-274, 2014.

[44] S. De Schepper, M. Dooms, and E. Haezendonck, "Stakeholder dynamics and responsibilities in public-private partnerships: a mixed experience," International Journal of Project Management, vol. 32, no. 7, pp. 1210-1222, 2014.

[45] R. E. Freeman, Strategic Management: A Stakeholder Approach, Cambridge University Press, Cambridge, UK, 2010.

[46] J. Nederhand and E. H. Klijn, "Stakeholder involvement in public-private partnerships: its influence on the innovative character of projects and on project performance," $A d$ ministration \& Society, vol. 51, no. 8, pp. 1200-1226, 2019.

[47] W. Xiong and D. Zhu, "Theory and practice of sustainability-oriented public private partnership," Journal of Tongji University, vol. 28, pp. 78-84, 2017.

[48] M. Yılmaz and A. Bakış, "Sustainability in construction sector," Procedia-Social Behavioral Sciences, vol. 195, pp. 2253-2262, 2015.

[49] A. Amiril, A. H. Nawawi, R. Takim, and S. N. F. A. Latif, "Transportation infrastructure project sustainability factors and performance," Procedia-Social and Behavioral Sciences, vol. 153, pp. 90-98, 2014.

[50] CeequalLtd, Ceequal Version 5.1, Assessment Manual for Projects, International Version, Ceequal Ltd., Watford, UK, 2013.

[51] S. Muench, J. Anderson, J. Hatfield, J. Koester, M. Söderlund, and C. Weiland, Greenroads Manual v1. 5, University of Washington, Seattle, WA, USA, 2011. 
[52] ISCA, Infrastructure Sustainability Rating Tool Technical Manual, Version 1.0, Infrastructure Sustainability Council of Australia (ISCA), Sydney, Australia, 2013.

[53] O. O. Ugwu, M. M. Kumaraswamy, A. Wong, and S. T. Ng, "Sustainability appraisal in infrastructure projects (SUSAIP): part 1. Development of indicators and computational methods," Automation in Construction, vol. 15, no. 2, pp. 239-251, 2006.

[54] L. Shen, Y. Wu, and X. Zhang, "Key assessment indicators for the sustainability of infrastructure projects," Journal of Construction Engineering and Management, vol. 137, no. 6, pp. 441-451, 2011.

[55] L.-Y. Shen, J. L. Hao, V. W.-Y. Tam, and H. Yao, "A checklist for assessing sustainability performance of construction projects," Journal of Civil Engineering and Management, vol. 13, no. 4, pp. 273-281, 2007.

[56] Y. Wang and Z. J. Zhao, "Motivations, obstacles, and resources," Public Performance \& Management Review, vol. 37, no. 4, pp. 679-704, 2014.

[57] J. Kivilä, M. Martinsuo, and L. Vuorinen, "Sustainable project management through project control in infrastructure projects," International Journal of Project Management, vol. 35, no. 6, pp. 1167-1183, 2017.

[58] R. K. Mavi and C. Standing, "Critical success factors of sustainable project management in construction: a fuzzy DEMATEL-ANP approach," Journal of Cleaner Production, vol. 194, pp. 751-765, 2018.

[59] A. Heravi, V. Coffey, and B. Trigunarsyah, "Evaluating the level of stakeholder involvement during the project planning processes of building projects," International Journal of Project Management, vol. 33, no. 5, pp. 985-997, 2015.

[60] R. Hueting, "Why environmental sustainability can most probably not be attained with growing production," Journal of Cleaner Production, vol. 18, no. 6, pp. 525-530, 2010.

[61] M. J. Hutchins and J. W. Sutherland, "An exploration of measures of social sustainability and their application to supply chain decisions," Journal of Cleaner Production, vol. 16 , no. 15, pp. 1688-1698, 2008.

[62] S. G. Banerjee, J. M. Oetzel, and R. Ranganathan, "Private provision of infrastructure in emerging markets: do institutions matter?" Development Policy Review, vol. 24, no. 2, pp. 175-202, 2006.

[63] C. Ménard, A. Peeroo, and R. Kunneke, "Liberalization in the water sector: three leading models," International Handbook of Network Industries: the Liberalization of Infrastructure, vol. 18, pp. 310-327, 2011.

[64] S. House, "Responsive regulation for water PPP: balancing commitment and adaptability in the face of uncertainty," Policy and Society, vol. 35, no. 2, pp. 179-191, 2016.

[65] H. Li, Q. Xia, L. Wang, and Y. Ma, "Sustainability assessment of urban water environment treatment public-private partnership projects using fuzzy logic," Journal of Engineering Design Technology, vol. 18, no. 5, pp. 1251-1267, 2020.

[66] M. Lundin and G. M. Morrison, "A life cycle assessment based procedure for development of environmental sustainability indicators for urban water systems," Urban Water, vol. 4, no. 2, pp. 145-152, 2002.

[67] R. A. Begum, C. Siwar, J. J. Pereira, and A. H. Jaafar, "Implementation of waste management and minimisation in the construction industry of Malaysia," Resources, Conservation and Recycling, vol. 51, no. 1, pp. 190-202, 2007.

[68] K. Hewage and A. Porwal, "Sustainable construction: an information modelling approach for waste reduction," in
Proceedings of the International Conference on Building Resilience, Kandalama, Sri Lanka, July 2011.

[69] M. A. Brown and B. K. Sovacool, "Developing an "energy sustainability index" to evaluate energy policy," Interdisciplinary Science Reviews, vol. 32, no. 4, pp. 335-349, 2007.

[70] O. O. Ugwu and T. C. Haupt, "Key performance indicators and assessment methods for infrastructure sustainability-a South African construction industry perspective," Building and Environment, vol. 42, no. 2, pp. 665-680, 2007.

[71] A. J. G. Silvius and R. P. J. Schipper, "Sustainability in project management: a literature review and impact analysis," Social Business, vol. 4, no. 1, pp. 63-96, 2014.

[72] J. Allouche and M. Finger, "Private sector participation in the water and sanitation sector... and the need for re-regulation," in Proceedings of the 3rd World Water Forum, Kyoto, Japan, March 2003.

[73] L. Beh, "Development and distortion of Malaysian publicprivate partnerships-patronage, privatised profits and pitfalls," Australian Journal of Public Administration, vol. 69, no. S1, pp. S74-S84, 2010.

[74] Z. Liu and H. Yamamoto, "Public-private partnerships (PPPs) in China: present conditions, trends, and future challenges," Interdisciplinary Information Sciences, vol. 15, no. 2, pp. 223-230, 2009.

[75] J.-S. Chou and D. Pramudawardhani, "Cross-country comparisons of key drivers, critical success factors and risk allocation for public-private partnership projects," International Journal of Project Management, vol. 33, no. 5, pp. 1136-1150, 2015.

[76] L. Y. Shen, V. W. Y. Tam, L. Tam, and Y. B. Ji, "Project feasibility study: the key to successful implementation of sustainable and socially responsible construction management practice," Journal of Cleaner Production, vol. 18, no. 3, 2010.

[77] S. Wasserman and K. Faust, Social network analysis: Methods and Applications, Vol. 8, Cambridge University Press, Cambridge, UK, 1994.

[78] K. Y. Mok, G. Q. Shen, and J. Yang, "Stakeholder management studies in mega construction projects: a review and future directions," International Journal of Project Management, vol. 33, no. 2, pp. 446-457, 2015.

[79] P. Chinowsky, J. Diekmann, and V. Galotti, "Social network model of construction," Journal of Construction Engineering and Management, vol. 134, no. 10, pp. 804-812, 2008.

[80] T. Yu, G. Q. Shen, Q. Shi, X. Lai, C. Z. Li, and K. Xu, "Managing social risks at the housing demolition stage of urban redevelopment projects: a stakeholder-oriented study using social network analysis," International Journal of Project Management, vol. 35, no. 6, pp. 925-941, 2017.

[81] X. Zheng, Y. Le, A. P. C. Chan, Y. Hu, and Y. Li, "Review of the application of social network analysis (SNA) in construction project management research," International Journal of Project Management, vol. 34, no. 7, pp. 1214-1225, 2016.

[82] C. Z. Li, J. Hong, F. Xue, G. Q. Shen, X. Xu, and M. K. Mok, "Schedule risks in prefabrication housing production in Hong Kong: a social network analysis," Journal of Cleaner Production, vol. 134, pp. 482-494, 2016.

[83] M. E. Newman, "Scientific collaboration networks. II. Shortest paths, weighted networks, and centrality," Physical Review E, vol. 64, no. 1, Article ID 016132, 2001.

[84] Y. Wang, Y. Wang, X. Wu, and J. Li, "Exploring the risk factors of infrastructure PPP projects for sustainable 
delivery: a social network perspective," Sustainability, vol. 12, no. 10, p. $4152,2020$.

[85] R. V. Gould and R. M. Fernandez, "Structures of mediation: a formal approach to brokerage in transaction networks," Sociological Methodology, vol. 19, pp. 89-126, 1989.

[86] S. T. Ng, J. M. W. Wong, and K. K. W. Wong, "A public private people partnerships (P4) process framework for infrastructure development in Hong Kong," Cities, vol. 31, pp. 370-381, 2013.

[87] S. Shi, H.-Y. Chong, L. Liu, and X. Ye, "Examining the interrelationship among critical success factors of public private partnership infrastructure projects," Sustainability, vol. 8, no. 12, p. 1313, 2016.

[88] C. F. Wright, "Leveraging reputational risk: sustainable sourcing campaigns for improving labour standards in production networks," Journal of Business Ethics, vol. 137, no. 1, pp. 195-210, 2016.

[89] E. J. Boyer, D. M. Van Slyke, and J. D. Rogers, "An empirical examination of public involvement in public-private partnerships: qualifying the benefits of public involvement in PPPs," Journal of Public Administration Research Theory, vol. 26, no. 1, pp. 45-61, 2016.

[90] J. Yuan, L. Zhang, Y. Tan, and M. J. Skibniewski, "Evaluating the regional social sustainability contribution of publicprivate partnerships in China: the development of an indicator system," Sustainable Development, vol. 28, no. 1, pp. 259-278, 2020.

[91] M. L. Martens and M. M. Carvalho, "Key factors of sustainability in project management context: a survey exploring the project managers' perspective," International Journal of Project Management, vol. 35, no. 6, pp. 1084-1102, 2017.

[92] J. Yang, L. Song, and Z. Xing, "Credit default of local public sectors in Chinese government-pay PPP projects: evidence from ecological construction," Advances in Civil Engineering, vol. 2019, Article ID 2138525, 19 pages, 2019.

[93] J. J. Kim, C. W. Goodwin, and S. Kim, "Communication turns green construction planning into reality," Journal of Green Building, vol. 12, no. 1, pp. 168-186, 2017.

[94] J. Du, H. Wu, and X. Zhao, "Critical factors on the capital structure of public-private partnership projects: a sustainability perspective," Sustainability, vol. 10, no. 6, p. 2066, 2018.

[95] K. C. Chew, "Singapore's strategies towards sustainable construction," The IES Journal Part A: Civil \& Structural Engineering, vol. 3, no. 3, pp. 196-202, 2010.

[96] S. Zheng, K. Xu, Q. He, S. Fang, and L. Zhang, "Investigating the sustainability performance of PPP-type infrastructure projects: a case of China," Sustainability, vol. 10, no. 11, p. 4162, 2018.

[97] L. Song, Y. Mohamed, and S. M. Abourizk, "Early contractor involvement in design and its impact on construction schedule performance," Journal of Management in Engineering, vol. 25, no. 1, pp. 12-20, 2009.

[98] H. P. Tserng, G.-F. Lin, L. K. Tsai, and P.-C. Chen, "An enforced support vector machine model for construction contractor default prediction," Automation in Construction, vol. 20, no. 8, pp. 1242-1249, 2011.

[99] B. Manos, M. Partalidou, F. Fantozzi, S. Arampatzis, and O. Papadopoulou, "Agro-energy districts contributing to environmental and social sustainability in rural areas: evaluation of a local public-private partnership scheme in Greece," Renewable and Sustainable Energy Reviews, vol. 29, pp. 85-95, 2014.
[100] M.-Q. Chen, "Analysis on system obstructions to small town sustainable development and countermeasures in China," China Population, Resources Environment, vol. 1, pp. 60-63, 2004.

[101] C. Qin and J. Wang, "On the development of mountain economy of China's western regions: based on ecological civilization," Ecological Economy, vol. 10, pp. 62-71, 2012.

[102] A. P. C. Chan, P. T. I. Lam, D. W. M. Chan, E. Cheung, and Y. Ke, "Critical success factors for PPPs in infrastructure developments: Chinese perspective," Journal of Construction Engineering and Management, vol. 136, no. 5, pp. 484-494, 2010. 